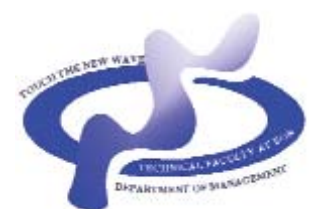

www.sjm06.com
Serbian

Journal

of

Management

\title{
APPLICATION OF STIMULUS \& RESPONSE MODEL TO IMPULSE BUYING BEHAVIOR OF ALGERIAN CONSUMERS
}

\author{
Amel Graa* and Maachou Dani-elKebir

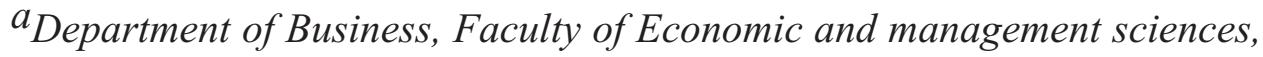 \\ Djilali Liabes University, Sidi Bel Abbes, Algeria
}

(Received 7 May 2011; accepted 13 September 2011)

\begin{abstract}
This paper investigates the influence of situational factors on the impulse buying behavior using a Mehrabian and Russell's (1974) framework (Stimulus \& response model). The results suggest that a consumer's emotions can be a mediating factor in the impulse purchase process. In this study, we identify and explore how situational factors and emotional states may influence various dimensions of impulse purchase behavior of Algerian shoppers. By tapping the responses of 687 consumers in the area of Algeria' west, we obtain that there is a positive relationship between independent and dependent variables.

According to the results, pleasure was associated with design, whereas arousal was associated with perception of crowding, but dominance was linked to time spent in the store. Retailers can take these findings to maintain trained their employees and provide adequate signs and best environment whenever some relocation of products took place.
\end{abstract}

Keywords: Impulse purchasing, Situational factors, Mehrabian \& Russell's model.

\section{INTRODUCTION}

Connected to social and economic changes in Algeria over the last decade, such as dramatic increases in disposable income, variety of products in local market and credit facilities, have produced a different climate in which individuals make consumer choices and as a result increase the behavior of impulse buying. It is important for the retail players to be able to understand the different factors affecting the extent in impulse buying

*Corresponding author: graa_amel@yahoo.fr

DOI: $10.5937 /$ sjm 1201053G 
behavior. So, there are many factors which affect Consumers Impulse Buying Behavior in Algerian market but we are only analyzing some situational factors which are: store environment (atmosphere, design and employee assistance), time pressure and perceived crowding.

The literature suggests that consumer emotions influence shopping behavior in a number of different ways, including impulse purchasing (Gardner \& Rook, 1988; Rook, 1987). In this sense, the current study aims to examine the role of situational factors that are: store environment, perceived crowding and time pressure in influencing Algerian consumer to do an impulse buying. In addition, the authors seek to investigate the association of the mediating variables that are emotional states as proposed by Mehrabian and Russell with, on the one hand, the independent variables that are the situational predictors and, Secondly, the dependent variable that is; impulse buying behavior of consumers who shop in the area of Algeria' west.

\section{THE LITERATURE REVIEW}

The importance of understanding impulse purchasing in retail stores was first identified in the marketing literature over sixty years ago (Clover, 1950). Impulse purchasing accounts for a substantial percentage of the products sold across a broad range of product categories (Colb \& Hoyer, 1986; Hausman, 2000; Rook \& Fischer, 1995). Research on impulse buying has been based on varying conceptual definitions of the construct and has focused primarily on in-store retailing.

A decade after Clover's (1950) preliminary research on impulse purchases, Stern (1962) delineated four distinct types of impulse buying: pure, reminder, suggestion, and planned impulse buying: (i) Pure impulse buying: is a novelty or escape purchase which breaks a normal buying pattern, (ii) Reminder impulse buying: occurs when a shopper sees an item or recalls an advertisement or other information and remembers that the stock at home is low or exhausted, (iii) Suggestion impulse buying: occurs when a shopper sees a product for the first time and visualizes a need for it, and (iv) Planned impulse buying: takes place when the shopper makes specific purchase decisions on the basis of price specials, coupon offers and the like.

Stern's (1962) contribution is quite significant, because even today most research studies use his concept of impulse purchases as a starting point (Beatty \& Ferrell, 1998; Rook, 1987).

Applebaum (1951) introduced the notion of exposure to stimulus into the concept of impulse buying, and defined impulse buying as "buying that presumably was not planned by the customer before entering a store, but which resulted from a stimulus created by a sales promotional device in the store". Although this was an improvement over the earlier definition, it was still a limited definition because the stimulus that Applebaum (1951) discussed is restricted to sales promotional devices in the store which the consumer could be using as an external memory aid. Over time, researchers began to look at consumer characteristics rather than product characteristics or stimuli as it was agreed that impulse purchasing is not confined to any particular product or product category (Rook, 1987). The hedonic or affective components of this type of purchasing became central in many studies (Cobb \& Hoyer, 1986; Piron, 1991; Rook, 1987; Weinburg \& Gottwald, 1982). Rook 
(1987) reported that consumers often felt a calling to purchase the product.

As researchers began to focus on the behavioral dimensions of impulse buying they moved away from viewing impulse buying as an unplanned purchase. Rook and Hoch (1985) state the growing consensus among researchers when they suggest that defining impulse purchasing as unplanned is neither a sufficient condition nor a necessary condition for construal as an impulse purchase, since consumers clearly use store layout as external memory aid. In fact, consumers may plan impulse buying. Rook (1987) discusses situations wherein consumers have occasionally described how they plan to go on impulse buying excursions.

Rook (1987) suggests impulse buying occurs: when a consumer experiences a sudden, often persistent urge to buy something immediately. The impulse to buy is hedonically complex and may stimulate emotional conflict. Also, impulse buying is prone to occur with diminished regard for its consequences.

\subsection{Situational factors influencing impulse buying behavior}

\subsubsection{Store environment}

Applebaum (1951) was among the first to suggest that the impulsive purchase can be conducted by the consumer's exposition at the time of his experience of shopping to a stimulus of the environment. In the same way, Stern (1962) showed the existence of a meaningful relation between the impulsive purchase and marketing techniques. These techniques create one favorable environment for the impulsive purchase. Some more recent works showed that the variable of the sales atmosphere (sounds, views and odors) are important stimulants that can produce the desire to buy impulsively (Eroglu \& Machleit, 1993; Mitchell, 1994; Donovan et al., 1994). Some elements as music, light and the display can affect the process of decision of the consumer (Underhill, 1999). Rook (1987) indicate that the sudden emergency to buy seems to be motivated by the visual confrontation with the product or by stimuli of the environment. Indeed, the interaction of the purchaser with the retail outlet is a main component of the impulsive purchase decisions (Phillips \& Bradshaw, 1993). In the same way, the design of the retail outlet is able of to give the pleasure and to stimulate the visitor of the store. The different components of the environment act directly on buyer' emotional states (Donovan \& Rossiter, 1982; Dowson et al., 1990; Hui \& Bateson, 1991). It be acceptable to indicate that Park and al., (2006) verified the negative impact of the interaction with employee assistance on the tendency to buy impulsively.

\subsubsection{Time pressure}

Stockdale (1978) suggested that people treat time as a scarce resource just as they do with space. Howard and Sheth (1969) define the pressure time that is the opposite of the available time for a shopper to do the act of purchase. Time pressure will limit the attention accorded to the elements of the environment. More the consumer spent time in the store, more he disposed to buy impulsively (Iyer, 1989); contrary to Au, et al. (1993), when they suggest that the impulsive purchase often achieves in the five first minutes of shopping and the probability of its realization decreases that the time passed. 


\subsubsection{Perceived crowding}

According to Stokols (1972), crowding results from both the density stimuli and personal perception of the environment. Extending the concept, the empirical studies conducted by Harrell, et al. (1980) and Machleit et al. (2005) identified two dimensions of perceived crowding, human crowding and spatial crowding. Human crowding refers to a closed, confined feeling experienced from high human density while spatial crowding refers to feelings of restricted physical body movement due to high spatial density. Several studies (for example, Zlutnik \& Altman, 1972; Stokols, 1976) demonstrated that when the environments restrict or interfere with an individual's activity, the individual perceives crowding. This concept implies that density describes a state of "emotional neutral", while crowding has to do with a state of strong emotional connection. Therefore, perceived crowding is supposed to act negatively as well on the realization of an impulsive purchase as well as on the emotional states of the shopper (Machleit et al., 2000). We note also, that research on perceived crowding postulates that spatial density is negatively correlated with satisfaction (e.g., Hui \& Bateson, 1991;
Machleit et al., 2005) and number of purchases (Grossbart et al., 1990) but human density is positively correlated with impulse purchasing (Jiunn-Ger, 2004).

\subsubsection{The Mehrabian-Russell Theory}

The fundamental proposition of Mehrabian and Russell's (1974) theory is that the impact of the situation on behavior is mediated by emotional responses, so that any set of conditions initially generates an emotional (affective, connotative, feeling) reaction, which in turn leads to a behavioral response (Figure 1). Further, the universe of all possible emotional responses may be represented by one or a combination of three basic dimensions: pleasure, arousal and dominance. Pleasure as an emotional state is distinguished from "preference, liking, positive reinforcement or approachavoidance... since the latter responses are also determined by the arousing quality of a stimulus" (Mehrabian \& Russell, 1974). It is a composite of feelings such as happiness, contentment and satisfaction, etc. Arousal is an activity orientation and is "a measure of how wide awake the organism is, of how ready it is to act". Finally, dominance is a reflection of the extent to which the individual feels in control of or overpowered

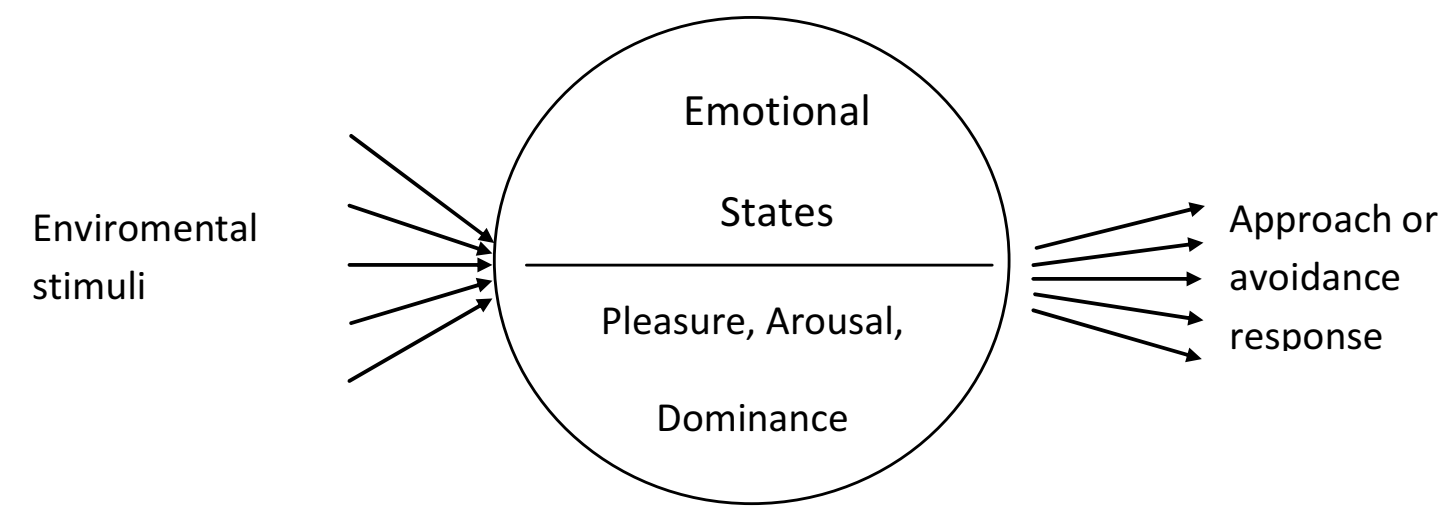

Figure 1. The Mehrabian-Russell model 
by his environment. The higher the level of dominance perceived in the situation, the more submissive is the state of the individual.

\section{HYPOTHESIS}

The following hypotheses were proposed for the study:

\section{Relationship of situational factors and emotional sates}

H1. There is a positive relationship between store environment and the emotions of pleasure, arousal and dominance, that shoppers experience during shopping.

H2. There is a positive relationship between perceived crowding and the emotions of pleasure, arousal and dominance, that shoppers experience during shopping.

H3. There is a positive relationship between time pressure and the emotions of pleasure, arousal and dominance, that shoppers experience during shopping.

Relationship of emotional sates and impulse purchasing behavior

H4. Shoppers' feelings of pleasure, arousal and dominance experienced during shopping at a store are positively related to impulse buying behavior.

\section{Relationship of situational factors and impulse purchasing behavior}

H5. Store environment has a positive correlation with the impulse buying behavior.
H6. Perceived crowding has a positive correlation with the impulse buying behavior.

H7. Time pressure has a positive correlation with the impulse buying behavior

\section{DATA AND SAMPLE}

\subsection{Methodology}

Population and Sample: The consumers, who shop in general stores, departmental stores, boutiques, shopping malls, small retail outlets in the area of Algeria West were taken as the population for this study. A convenience sample (non-probability sampling method) of 687 consumers was pooled up for the current study.

\subsection{Instrumentation}

The instrument contained sub-parts. These sub-parts were retrieved from different previous studies. The behavioral aspect of impulse buying in which items were arranged to measure the impulse buying tendency was adopted from the paper of Rook and Fisher (1995) and then further modified. Whereas, the attitudinal aspect of impulse buying in which items were arranged to measure frequency was adopted from the paper of Kacen and Lee (2002) and then further modified. The sub-part of the questionnaire regarding Store environment was adopted from the paper of Greenland and McGoldrick (1994), where items are measured on three dimensions: design, employee assistance and atmosphere. The sub-part of the questionnaire regarding time pressure was adopted from the paper of 
Beatty and Ferrell (1998), where items are measured on three dimensions using a likert scale.The sub-part of the questionnaire regarding perceived crowding was adopted from the paper of Hui and Bateson (1991). It was captured via two dimensions human and spatial crowding where are measured in three-item scale (authors should please revise this part). The sub-part of the questionnaire regarding emotional states was measured through three dimensions: pleasure, arousal and dominance from Mehrabian and Russell's model (1974). Indeed, several studies have tested the reliability and the validity of this scale (Graillot, 1998).After collecting 100 responses the reliability of the instrument was checked using Statistical Package for Social Sciences (SPSS). The value of Cronbach's Alpha was 0.705, which confirmed the reliability of the instrument and then further responses up to 687 were collected (Stefanovic et al., 2011).

\section{RESULTS AND DISCUSSION}

The findings on the extent of impulsive purchases are inconsistent with previous researchers such as Hausman (2000) who obtained between 30 and 50 percent of impulse purchases among the total amount of purchases. In present study, researchers obtain between 23 and 27 percent of impulse purchases.

The respondents ranged from small shops to mega furniture outlets. There were 369 women and 318 men. Ages ranged from 18 to 73 years $($ Mean age $=37.3$ years, Standard Deviation $=12.4$ years). Sixty seven participants' highest education was elementary school or high school, for 134 participants this was a vocational study, for
316 this was college or university, and 94 respondents were currently studying. Seventy six participants were illiterates.

To establish if emotional states were a mediating force between social factors and impulse purchase behavior, we ran a multiple regression analysis:

The data presented in Table 1, 2 and 3; show the results extracted on the basis of multiple regression to find the association level between the Independent, moderating and the dependent variables. The tests of hypotheses revealed the following results:

Coefficients of the impact of store environment on both emotional states (pleasure and arousal) on pleasure (beta= $0.534, \mathrm{p}<.001$ ), and arousal (beta $=0.333$, $\mathrm{p}<.001)$ are significant, but is not significant for dominance $(p>.001)$. These results provide support for H1a and $\mathrm{H} 1 \mathrm{~b}$, but $\mathrm{H} 1 \mathrm{c}$ is rejected. Nevertheless, the result supports H1.

The relationship between perceived crowding and emotional responses is not significant. Feelings of pleasure and arousal are negatively related to perceived crowding (beta $=-0.511$, beta $=-0.344, p>.001, p>.001$ ), this lending to reject $\mathrm{H} 2 \mathrm{a}$ and $\mathrm{H} 2 \mathrm{~b}$. Opposing to results of pleasure and arousal, feelings of dominance are positively related to perceived crowding(beta $=0.267, \mathrm{p}<.001)$. Thus, H2c is supported.

There is a relationship between time pressure and emotional responses. However, the results showed in Table 1 demonstrate that the feelings of time pressure at the store contribute a negative feelings of pleasure and dominance, this provide reject $\mathrm{H} 3 \mathrm{a}$ and $\mathrm{H} 3 \mathrm{c}$. The coefficients for the impact of shoppers that have little of time for shopping on their feelings of arousal is positive and significant $(p<.001)$. Thus, H3b is supported.

Hypothesis 4 stated that shoppers' 
feelings of pleasure, arousal, and dominance the behavior of shoppers to do an impulse experienced during shopping at a store are purchase. The third dimension, dominance, positively related to impulse buying showed a negative relationship with impulse

Table1. Statistical analysis for relationship of Social factors and emotional states

\begin{tabular}{|c|c|c|c|c|c|c|c|}
\hline $\begin{array}{l}\text { Dependant } \\
\text { variable }\end{array}$ & Independent variables & $\beta$ & S.E & Wald & $d f$ & sig & $\operatorname{Exp}(\beta)$ \\
\hline \multirow[t]{3}{*}{$\begin{array}{l}\text { Emotional } \\
\text { state } \\
\bullet \text { Pleasure }\end{array}$} & $\begin{array}{l}\text { H1a Store environment } \\
\text { - Atmosphere } \\
\text { - Design } \\
\text { - Personal } \\
\\
\quad \text { Assistance }\end{array}$ & $\begin{array}{l}0.534 \\
1.513 \\
0.068 \\
-0.258\end{array}$ & $\begin{array}{l}0.345 \\
0.475 \\
0.228 \\
0.228\end{array}$ & $\begin{array}{l}6.870 \\
10.14 \\
1 \\
0.089 \\
1.283\end{array}$ & $\begin{array}{l}1 \\
1 \\
1 \\
1\end{array}$ & $\begin{array}{l}0.001 \\
0.001 \\
-0.257 \\
0.004\end{array}$ & $\begin{array}{l}3.456 \\
4.540 \\
1.070 \\
0.772\end{array}$ \\
\hline & $\begin{array}{r}\text { H2a } \\
\text { - } \quad \text { Human crowding } \\
\text { - } \quad \text { Spatial crowding }\end{array}$ & $\begin{array}{l}-0.511 \\
-0.655 \\
0.184\end{array}$ & $\begin{array}{l}0.588 \\
0.877 \\
0.285\end{array}$ & $\begin{array}{l}0.376 \\
0.045 \\
1.067\end{array}$ & $\begin{array}{l}1 \\
1 \\
1\end{array}$ & $\begin{array}{l}0.421 \\
0.345 \\
0.553\end{array}$ & $\begin{array}{l}0.997 \\
1.201 \\
0.333\end{array}$ \\
\hline & H3a Time pressure & -0.030 & 0.212 & 0.020 & 1 & 0.889 & 0.971 \\
\hline \multirow[t]{3}{*}{$\begin{array}{l}\text { Emotional } \\
\text { state } \\
\text { - Arousal }\end{array}$} & $\begin{array}{cl}\text { H1b } & \text { Store environment } \\
\text { - } & \text { Atmosphere } \\
\text { - } & \text { Design } \\
\text { - } & \text { Personal } \\
& \text { Assistance } \\
\end{array}$ & $\begin{array}{l}0.333 \\
1.267 \\
0.068 \\
-0.258\end{array}$ & $\begin{array}{l}0.388 \\
0.475 \\
0.228 \\
0.228\end{array}$ & $\begin{array}{l}3.479 \\
3.356 \\
3.460 \\
3.657\end{array}$ & $\begin{array}{l}1 \\
1 \\
1 \\
1\end{array}$ & $\begin{array}{l}0.002 \\
-0.067 \\
-0.047 \\
0.056\end{array}$ & $\begin{array}{l}3.126 \\
4.540 \\
1.070 \\
0.772\end{array}$ \\
\hline & $\begin{array}{r}\text { H2b } \\
\text { - } \quad \text { Human crowding crowding } \\
\text { - } \quad \text { Spatial crowding }\end{array}$ & $\begin{array}{l}-0.344 \\
-0.646 \\
0.131\end{array}$ & $\begin{array}{l}0.577 \\
0.622 \\
0.585\end{array}$ & $\begin{array}{l}0.784 \\
1.080 \\
0.050\end{array}$ & $\begin{array}{l}1 \\
1 \\
1\end{array}$ & $\begin{array}{l}0.466 \\
0.345 \\
0.553\end{array}$ & $\begin{array}{l}0.863 \\
1.201 \\
0.333\end{array}$ \\
\hline & H3b Time pressure & 0.184 & 0.148 & 1.544 & 1 & 0.214 & 1.201 \\
\hline \multirow[t]{3}{*}{$\begin{array}{l}\text { Emotional } \\
\text { state } \\
\text { - Dominance }\end{array}$} & $\begin{array}{c}\text { H1c } \text { Store environment } \\
\text { - Atmosphere } \\
\text { - Design } \\
\text { - Personal } \\
\\
\quad \text { Assistance }\end{array}$ & $\begin{array}{l}-0.111 \\
-0.131 \\
0.646 \\
0.356\end{array}$ & $\begin{array}{l}0.596 \\
0.585 \\
0.622 \\
0.600\end{array}$ & $\begin{array}{l}0.652 \\
0.050 \\
1.080 \\
0.352\end{array}$ & $\begin{array}{l}1 \\
1 \\
1 \\
1\end{array}$ & $\begin{array}{l}0.461 \\
0.823 \\
0.299 \\
0.553\end{array}$ & $\begin{array}{l}0.844 \\
1.139 \\
0.524 \\
0.701\end{array}$ \\
\hline & $\begin{array}{r}\text { H2c } \text { Perceived crowding } \\
\text { - Human crowding } \\
\text { - Spatial crowding }\end{array}$ & $\begin{array}{l}0.267 \\
0.265 \\
0.200\end{array}$ & $\begin{array}{l}0.120 \\
0.145 \\
0.107\end{array}$ & $\begin{array}{l}3.386 \\
3.356 \\
3.460\end{array}$ & $\begin{array}{l}1 \\
1 \\
1\end{array}$ & $\begin{array}{l}-0.955 \\
0.067 \\
-0.063\end{array}$ & $\begin{array}{l}1.267 \\
1.303 \\
1.221\end{array}$ \\
\hline & H3c Time pressure & -0.009 & 0.049 & 0.067 & 1 & 0.465 & 0.456 \\
\hline
\end{tabular}

behavior. The results of multiple regression analysis for relationships between emotional responses and impulse purchase behavior (Table 2) indicate that feelings of pleasure and arousal were positively related to impulse purchase behavior (beta $=0.175$, beta $=0.336, \mathrm{p}<.001, \mathrm{p}<.001)$. These positive impacts of the feelings of pleasure and arousal on the selected behavior mean that the feelings of pleasure and arousal are strong emotions that can make a pressure on purchase behavior ( Thus, H4 was partially supported.

The effects of the store environment on the impulse purchase behavior were examined through the hypothesis 5. As shown in Table 3, the results support the hypothesis that store environment is positively related to impulse buying behavior, atmosphere (beta $=0.265, \mathrm{p}<.001$ ), design (beta $=0.200, \mathrm{p}<.001$ ), and personal assistance (beta $=0.289, \mathrm{p}<.001$ ). Thus, H5 
Table2. Statistical analysis for relationship of emotional states and impulse buying behavior

\begin{tabular}{|l|l|l|l|l|l|l|l|}
\hline $\begin{array}{l}\text { Dependant } \\
\text { variable }\end{array}$ & Independent variables & $\boldsymbol{\beta}$ & S.E & Wald & $\boldsymbol{d} \boldsymbol{f}$ & $\boldsymbol{s i g}$ & $\boldsymbol{E x p}(\boldsymbol{\beta})$ \\
\hline $\begin{array}{l}\text { Impulse } \\
\text { purchasing }\end{array}$ & $\begin{array}{r}\text { H4 Emotional states } \\
-\quad \text { H4a Pleasure }\end{array}$ & 0.175 & 0.056 & 0.635 & 1 & -0.890 & 1.258 \\
& $-\quad$ H4b Arousal & 0.336 & 0.168 & 1.986 & 1 & 0.001 & 1.369 \\
& $-\quad$ H4c Dominance & -0.355 & 0.158 & 0.166 & 1 & 0.256 & 1.486 \\
\hline
\end{tabular}

was supported. The results show that the design of the store most strongly affected impulse behavior, followed by atmosphere factor, while the personal support had the least effect of the three dimensions of store environment.

Hypothesis H6 predicted there is a positive relationship between overall perceived store crowding and the impulse buying behavior of the consumers. This hypothesis was tested using simple regression analysis. As shown in Table 3, significant positive relationships were found between overall perceived crowding and the behavior of impulse purchase, spatial crowding (beta $=0.187, \mathrm{p}<.001$ ) and human crowding (beta $=0.131, \mathrm{p}<.001$ ). Therefore, Hypothesis 6 was supported.

Hypothesis $\mathrm{H} 7$ proposed a positive relationship between time pressure and impulse buying behavior of the consumers.
For simple regression analysis, time pressure was used as an independent variable and impulse buying behavior as a dependent variable. The results are shown in Table 3, time pressure had no significant effect on impulse purchase behavior of the consumers during their shopping experience at the store. Thus, Hypothesis 7 was rejected.

\section{CONCLUSION}

Our study findings indicate that social factors influence emotional states of Algerian shoppers. The presence of environmental simulation variables such as scent and sound or attractive store displays affect positively shoppers' feelings of pleasure and arousal, but it has a negative impact on self control for purchase. The results show that perceived crowding tends

Table3. Statistical analysis for relationship of social factors and impulse buying behavior

\begin{tabular}{|c|c|c|c|c|c|c|c|}
\hline $\begin{array}{l}\text { Dependant } \\
\text { variable }\end{array}$ & Independent variables & $\beta$ & S.E & Wald & $d f$ & sig & $\operatorname{Exp}(\beta)$ \\
\hline $\begin{array}{l}\text { Impulse } \\
\text { purchasing }\end{array}$ & $\begin{array}{c}\text { H5 Store environment } \\
\text { - Atmosphere } \\
\text { - Design } \\
\text { - Personal } \\
\\
\text { Assistance }\end{array}$ & $\begin{array}{l}0.265 \\
0.200 \\
0.289\end{array}$ & $\begin{array}{l}0.145 \\
0.107 \\
0.151\end{array}$ & $\begin{array}{l}3.356 \\
3.460 \\
3.657\end{array}$ & $\begin{array}{l}1 \\
1 \\
1\end{array}$ & $\begin{array}{l}-0.067 \\
-0.063 \\
0.000\end{array}$ & $\begin{array}{l}1.303 \\
1.221 \\
1.335\end{array}$ \\
\hline $\begin{array}{l}\text { Impulse } \\
\text { purchasing }\end{array}$ & $\begin{array}{c}\text { H6 Perceived crowding } \\
\text { • } \quad \text { Human crowding } \\
\text { - }\end{array}$ & $\begin{array}{l}0.187 \\
0.131\end{array}$ & $\begin{array}{l}0.622 \\
0.585\end{array}$ & $\begin{array}{l}1.080 \\
0.050\end{array}$ & $\begin{array}{l}1 \\
1\end{array}$ & $\begin{array}{l}0.000 \\
-0.823\end{array}$ & $\begin{array}{l}0.524 \\
1.139\end{array}$ \\
\hline $\begin{array}{l}\text { Impulse } \\
\text { purchasing }\end{array}$ & H7 Time pressure & $\overline{0}-\overline{0}$ & 0.027 & 0.015 & 1 & 0.902 & 0.997 \\
\hline
\end{tabular}


to have a negative impact on emotional states; these findings are consistent with previous studies (Bitner, 1990; Van Dolen et al., 2002; Hui \& Bateson, 1991; Machleit et al., 2005). So, this study suggests that store managers might be able to reduce the negative effect of crowding by training their employees to be extra friendly at busy times. For the third factor "time pressure", the impact on both emotional responses (pleasure and dominance) is negative, but it has a positive impact on emotional state of arousal. This means that when consumers have less time in purchasing, they feel more arousal and less pleasure and less self control.

The present study uses Stimulus and Response model (Mehrabian \& Russell, 1974) to measure shoppers' emotional reactions (pleasure, arousal, and dominance) since it has been frequently used for evaluation of emotions in the retail setting environment. However, we suggest that emotional states may moderate the situational factors and in making impulse purchases; in this sense, the study determines the emotional states affecting impulsive purchases. The results advise that pleasant store environments lead to enhanced impulse buying. The positive effect of a highly agreeable store environment on impulse purchase is reliable with Mattila and Wirtz (2008). High arousal also tends to reduce people's ability to think through their actions (Leith \& Baumeister, 1996). But dominance feelings or shoppers' self control tends to reduce the behavior of impulse purchasing.

More importantly, this study highlights the situational factors influencing impulse purchase behavior in the store among shoppers. Store environment appears to be a significant factor, to promote impulse buying; retailers should create a store environment where the negative perceptions of impulse are reduced, stores should have highly legible environment and implement steps to promote shopping efficiency. This implies that marketers and retailers need to design shopping environment that reduce the expected shopping difficulties of their target consumers. It is important to understand that shoppers have varying types and amounts of product and store knowledge, which may affect their navigational search strategies. Time pressure affects the unplanned purchase in such way its realization increase that the time for shopping passed. These results are consistent with previous research such as Iyner (1989). The findings do not support the proposal of Grossbart et al. (1990) that shoppers do not an impulse buying behavior when they perceive the store crowding. The study of the impact of perceived crowding on the unplanned purchases showed that both the spatial crowding and human crowding had a positive influence on this behavior. These findings are consistent with Jiunn-Ger (2004) suggestion that human density is positively correlated with impulse purchasing. 


\title{
ПРИМЕНА МОДЕЛА СТИМУЛАЦИЈЕ И РЕАКЦИЈЕ НА ПОНАШАЊЕ ИМПУЛСИВНИХ КУПАЦА У АЛЖИРУ
}

\author{
Amel Graa and Maachou Dani-elKebir
}

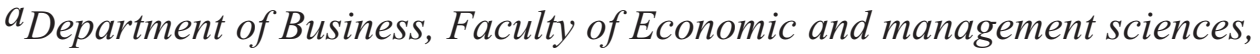
Djilali Liabes University, Sidi Bel Abbes, Algeria

\section{Извод}

Овај рад истражује утицај ситуационих фактора на понашање импулсних купаца употребом Mehrabian и Russell's (1974) оквира (Стимуланс \& реакција модел). Резултати предлажу да купчеве емоције могу бити одлучујући фактор у процесу импулсне куповине. У овој студији, истраживано је како ситуациони фактори и емоционална стања могу утицати различите димензије импулсицне куповине Алжирских купаца. Снимањем реакција 687 корисника у региону западног Алжира, закључено је да постоји позитивна релација између независне и зависних промењивих.

Према резултатима, задовољство је повезано са дизајном, док је узбуђење повезано са прихватањем паковања и амбалаже, али је најдоминантнија емоција повезана са временом проведеним у радњи. Велике трговине могу преузети резултате овог истраживања како би вршили додатну обуку својих запослених и омогућили адекватне сигнале и позицију на коју производи који се продају треба да буду смештени у радњи.

Кључне речи: Импулсна куповина, Ситуациони фактори, модел Mehrabian и Russell's.

\section{References}

Applebaum, W. (1951) Studying Consumer Behavior in Retail Scores. Journal of Marketing, 16: 32-40.

Au, A., Tse, A., \& Yip, K. (1993) A study of impulsive buying in Hong Kong. Emerging Issues in Marketing Annual Conference, 15-24.

Beatty, S., \& Ferrell, E. (1998) Impulse buying: modelling its precursors. Journal of Retailing, 2: 169-191.

Bitner, M.J. (1990) Evaluating service encounters: the effects of physical surroundings and employee responses. Journal of Marketing, 54: 69-82.

Clover, V.T. (1950) Relative importance of impulse buying in retail stores. Journal of marketing, 25 (Juillet) : 66-70.

Cobb, C.J., \& Hoyer, W.D. (1986) Planned versus impulse purchase behavior. Journal of Retailing, 62: 384-409.

Donovan, R.J., Rossiter, J.R., Marcoolyn, G., \& Nesdale, A. (1994) Store atmosphere and purchasing behavior. Journal of Retailing, 70: 283-294.

Donovan, R., \& Rossiter, R. (1982) Store Atmosphere: an environmental psychology approach. Journal of Retailing, 58: 34-57.

Dawson, S., Bloch, P., \& Ridgway, M. (1990) Shopping motives, emotionnal states, and retail outcomes, Journal of Retailing, 66: 408-427.

Eroglu, S.A., \& Machleit, K.A. (1993) Atmospheric in the retail environment: sights, sounds and smells. Advances in 
Consumer Research, 20: 34-55.

Gardner, M.P., \& Rook, D.W. (1988) Effects of impulse purchases on consumers' affective states. Advances in Consumer Research, 15: 127-130.

Graillot, L. (1998) Emotions et comportement du consommateur. Recherche et Applications en Marketing, 13 : 5-23.

Greenland, S.J., \& Mc Goldrick, P.J. (1994) Atmospherics, Attitudes and Behavior : Modelling the Impact of Designed Space. The International Review of Retail, Distribution and Consumer Research, 1(4): 1-16.

Grossbart, S., Hampton, R., Rammohan, B., \& Lipidus, R.S. (1990) Environmental dispositions and customer response to store atmospherics. Journal of Business Research, 21: 225-241.

Han, Y.K., Morgan, G.A., Kotsiopulos, A., \& Kang, P.J. (1991) Impulse buying behavior of apparel purchases. Clothing and Textile Research Journal, 9(3):15- 21.

Harrell, G.D., Hutt, M., \& Anderson, J.C. (1980) Path analysis of buyer behavior under conditions of crowding. Journal of Marketing Research, 17 (February): 45-51.

Hausman, A. (2000) A multi-method investigation of consumer motivations in impulse buying behavior. Journal of Consumer Marketing, 17: 403-419.

Howard, John A., \& Jadish, N. Sheth (1969). The Theory of Buyer Behavior, New York, NY: Wiley and sons.

Hui, M., \& Bateson, G. (1991) Perceived control and the effect of crowding and consumer choice on the service encounter. Journal of Consumer Research, 18: 174-184.

Iyer, E. (1989) Unplanned purchasing knowledge of shopping environment and time pressure. Journal of Retailing, 65: 4057.

Jiunn-Ger, L. (2004). The effects of store physical environment on perceived crowding and shopping behavior, thesis , Auburn university, Alabama, USA.

Kacen, J.J., \& Lee, J.A. (2002) The Influence of Culture on Consumer Impulse Buying Behavior. Journal of Consumer Impulse Buying Behavior, 12(2): 163-176.

Leith, K., \& Baumeister, R. (1996) Why do bad moods increase self-defeating behavior? Emotion, risk taking and selfregulation. Journal of Personality \& Social Psychology, 71: 1250-67.

Machleit, KA., \& Mantel, S.P. (2000) Emotional response and shopping satisfaction: moderating effects of shopper attributions. Journal of Business Research, 54: $97-106$

Machleit, K., Eroglu, S., \& PowellMantel, S. (2005) Perceived crowding and shopping satisfaction: what modifies this relationship? Journal of Consumer Psychology, 9(1): 29-42.

Mattila, A., \& Wirtz, J. (2008) The role of store environmental stimulation on impulse purchasing. Journal of Services Marketing, 22(2): 562-567.

Mehrabian, A., \& Russell, A. (1974). An approach to environmental psychology. Cambridge, Mass: MIT Press.

Mitchell, D.J. (1994) For the smell of it all: functions and effects of olfaction in Consumer Behavior. Advances in Consumer Research, 21: 330-345.

Park, E.J., Kim, E.Y. \& Forney, J.C. (2006) A Structural model of Fashionoriented Impulse Buying Behavior. Journal of Fashion Marketing and Management, 10(4): 433-446.

Philipps, H., \& Bradshow, R. (1993) How the customers actually shop: customer interaction with the point sale. Journal of the Market Research Society, 35.

Piron, F. (1991) Defining impulse 
purchasing. Advances in Consumer

Research, 18: 509-514.

Rook, D.W., \& Fisher, R.J. (1995) Normative influences on impulsive buying behavior Journal of Consumer Research, December, 22: 305 - 313.

Rook, D.W. (1987) The buying impulse. Journal of Consumer Research, 14, 189-199.

Rook, D.W., \& Hoch, S.J. (1985) Consuming impulses. Advances in Consumer Research, 12: 23-27.

Stefanovic, I., Rankovic, Lj., \& Prokic, S. (2011) Entrepreneurs motivational factors: Empirical evidence from Serbia. Serbian Journal of Management, 6(1): 73-83.

Stern, H. (1962) The significance of impulse buying today. Journal of Marketing, 26: 59-62.

Stockdale, J.E. (1978) Crowding: determinants and effects. Advances in Experimental Social Psychology, 11: 197-247.

Stokols, D. (1972) On the distinction between density and crowding. Psychological Review, 79: 275-277.

Stokols, D. (1976) The experience of crowding in primary and secondary environments. Environment and Behavior, 8: 49-85.

Underhill, P. (1999). Why We Buy: The Science of Shopping”. New York: Simon \& Schuster.

Van Dolen, W., Lemmink, J., \& Ruyter, K. (2002) Customer-sales employee encounters: a dyadic perspective. Journal of Retailing, 78(4): 265-81.

Zlutnik, S., \& Altman, I. (1972) Environment and the social sciences: Perspectives and application. American Psychological Association: 44-58.

Weinberg, P. \& Gottwald, W. (1982) Impulsive consumer buying as a result of emotion. Journal of Business research, 10(1): 43-57. 